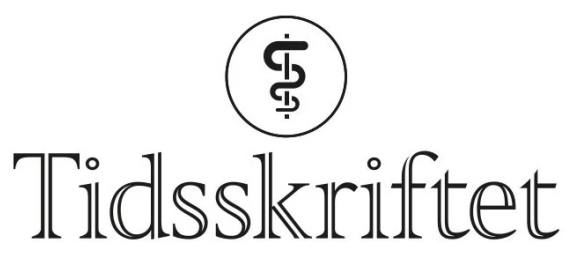

DEN NORSKE LEGEFORENING

\title{
Oksykodon mot rastløse bein?
}

KOMMENTAR

HELGE WAAL

helge.waal@medisin.uio.no

Helge Waal er professor emeritus, Senter for rus- og avhengighetsforskning (SERAF) og Universitetet i Oslo.

Forfatteren har ikke oppgitt noen interessekonflikter.

I en ellers klar og fornuftig lederartikkel om tiltak ved rastløse bein (1) anbefaler Einar Kinge bruken av opiat som tredjevalg etter gabapentin/pregabalin som førstevalg og dopaminagonister som annetvalg. Rastløse bein er oftest en kronisk tilstand, ikke sjelden sammen med ulike andre plager og lidelser. Opiater er som kjent sterkt avhengighetsfarlige medikamenter, og det er i økende grad klart at bruken så langt mulig skal begrenses til akutte og tidsavgrensete tilstander. Særlig varsomhet bør viser om pasienten har psykiske vansker eller rusproblemer.

Einar Kinge nevner ikke noe av dette. Hva mer er: Han anbefaler oksykodon som særlig egnet. Dette er vanskelig å forstå. Forskrivningen av oksykodon har hatt en sentral rolle i utviklingen av den svære amerikanske opioidepidemien som siste år har ført til opp mot 100 ooo dødsfall. Vi har ikke hatt noen slik epidemi i Norge, men også her har forskrivningen av oksykodon $\emptyset \mathrm{kt}$ de siste årene. I den norske statistikken over overdosemortalitet tilskrives «andre opioider» (oksykodon, morfin osv.) en økende rolle mens heroin har hatt en minkende. Det kan føyes til at oksykodon i blant omtales som «pilleheroin» blant tunge rusbrukere i Oslo.

Det er ønskelig at Einar Kinge modifiserer sine medikamentanbefalinger ved behandling av rastløse bein.

\section{LITTERATUR}

1. Kinge E. Rastløse bein er et folkehelseproblem. Tidsskr Nor Legeforen 2021; 141. doi: 10.4045/tidsskr.21.0733. [PubMed][CrossRef]

Publisert: 10. januar 2022. Tidsskr Nor Legeforen. DOI: 10.4045/tidsskr.21.0864

(C) Tidsskrift for Den norske legeforening 2023. Lastet ned fra tidsskriftet.no 26. april 2023. 